\title{
INFORMATION TECHNOLOGY AND BANKING SECTOR WITH REFERENCE TO CUSTOMER SATISFACTION
}

\author{
K.J. Raman* and A. Marcus**
}

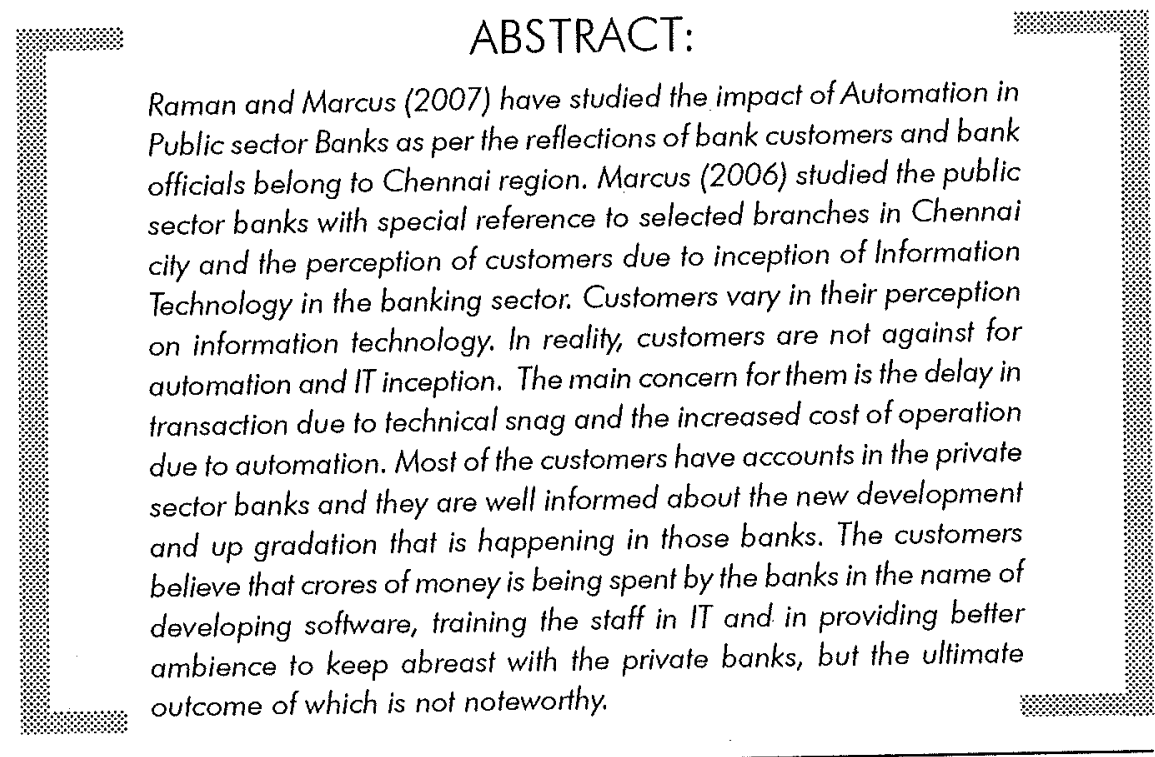

* Faculty of School of Management, Universiti Sains Malaysia (USM), Penang, Malaysia.

* Faculty of Department of Commerce, Loyola College, Chennai - 600034. 
The present study is based on the reflections of 674 bank customers of the public sector banks who have various types of bank accounts in the branches of Chennai city. Branches of public sector banks in Chennai city, consisting of 19 nationalized banks and State Bank of India with its 7 Associates were covered in the process. A wide range of customers through various domains of banking operations have been studied to identify their overall perception.

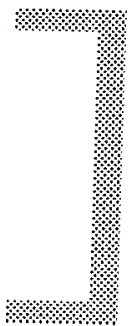

\section{Introduction}

Madan Goyal (1994) has observed that India which has a large network of bank branches and a vary large clientele base, too little and too late automation has resulted in very low profitability, poor customer services, gigantic arrears in unbalanced accounts and a large number of frauds. The future of banking is inextricably inter-woven within that of Automation. The Banking industry can ill afford to ignore the benefits flowing from automation. The Bank executives with technological skills have a better chance to assimilate new knowledge of automation and use it effectively. Doreswamy (1997) observed that the advent of multinational banks into the banking arena has increased competition, resulting in the contented customer of low profile to get a flavour of the benefit of competition. It is hence, pertinent for banks to tone up the interpersonal skills in their front line staff, which would meaningfully contribute to the basic satisfaction of the customers. Kaujalgi (1999) observed that customer satisfaction is a major contributor to customer retention and employees' interaction with the customers can directly influence customer satisfaction, either positively or negatively. He also opines that customers yet prefer human interaction and service delivery to other modes of interaction. Rao (2002) has analyzed the impact of new technology on banking sector. The advent of technology both in terms of computers and communications have been changing totally the ways and doing of banking business. Technology has opened new vistas and in turn brought new possibilities everyday for doing the same work differently and in a most cost-effective manner.

The study identifies the issues pertaining to the customers' perception on IT inception in the public sector banks and attempts to bring their perception with regard to the automation in the banks in which they have accounts.

\section{Methodology}

The standardized questionnaire suitable to Indian banking set-up was formulated and administered for customers of public sector banks. The selected bank customers were contacted and their responses were collected. 
The questionnaire consists of the following sections: Section A - Personal Profile: $\ln$ this section, multiple choice questions were framed to elicit responses on demographic characteristics such as age, sex, educational status, occupation, monthly income, name of the public sector bank in which they have accounts, branch location, frequency of operation, number of years of holding accounts, types of accounts they are holding, reasons for selecting the branch and whether they have accounts in any private bank other than the Public Sector Bank.

Section B - Response from the bank customers on Automation: In this section, respondents were asked to give their opinion on a 5-point rating scale on Customer Relationship, Cost of operation, Banking products/services, Flaws due to IT, Single window concept, Extended Banking Hours, Automation, Ambience, Competition and Overall assessment about before and after automation.

\section{Results and Discussion}

\subsection{Socio-Demographic Details of Bank Customers}

\section{Gender distribution}

Out of 674 bank customers taken for the study, 202 (30\%) were female customers and $472(70 \%)$ were male customers and thus male customers dominate transactions in Public Sector Banks.

\section{Educational status}

It is observed in the sample that $325(48 \%)$ were Graduates followed by $130(19 \%)$ were Post-Graduates, $118(16 \%)$ of them have educational qualification from $6^{\text {th }}$ to $12^{\text {th }}$ standard and $67(10 \%)$ were Professionals. Customers with no educational background and studied upto $5^{\text {th }}$ standard were very meager in number. Thus, both Graduates and Post-Graduates put together account for $67 \%$, which reveals that education has its own impact on the banking practice.

\section{Occupation}

The study also took a wide range of bank customers from housewives to retired persons to find their perception level on the issues. It was found that customers in 
the working class form more than $75 \%$ of the sample than the retired persons, housewives and students. Thus this proportion of representation reveals that the customers who could understand the importance of IT and its effect on bank services has responded in a large scale.

\section{Age in years}

About $290(43 \%)$ customers are below 30 years age group and more than $50 \%$ of the bank customers belong to $30-50$ years age group. Thus, altogether $93 \%$ of the respondents of the age group between 20 and 50 years are actively involved in the banking operations and more receptive to lechnological change than the customers of less than 20 years or more than 50 years old.

\section{Monthly income in rupees}

The average \pm standard deviation of salary per month of the sample is Rs. 13, 569 $\pm 20,904$. The large value in the form of standard deviation is understandable as the sample consists of wide spectrum of occupation.

\subsection{Interaction of Customers with Their Banks}

\section{Number of years of holding account}

The average \pm standard deviation of the number of years of holding account is $6.80 \pm 6.97$ years. Hence, the respondents are really competent enough to share their experiences about their respective banks and this will ultimately enhance the findings of the study.

\section{Types of accounts the customer is holding}

Through this study, it is clear that close to $90 \%$ of the customers have saving accounts and less than $5 \%$ of them had either recurring deposit account or Loan account. It simply highlights the fact that the customers of the public sector banks have their loan commitment with the private sector banks. It also cautions that the private sector banks have scope to convert the loan customers into their deposit customers in the near future. There could be many reasons for this like - better 
ambience, speedy discharge, less formalities and personal care towards customers provided by the private sector banks.

\section{Reason for selecting this branch}

The proximity of the bank closer to customer's residence is the primary criteria for starting an account in the bank and is favored by $353(52 \%)$ out of 674 customers. Understandably, this reason will definitely enable the customer to withdraw money in case of emergency and for easy accessibility. Surprisingly, only $52(8 \%)$ customers select the branch exclusively for computer environment prevailing in the branch, which shows that automation has not become an attracting element in the public sector banks even though computerization process is going on for so long.

\section{Bank accounts in any private banks}

As much as 284 (42\%) customers of the public sector banks have accounts in the private sector banks as well, which is an alarming response found in this study. It is a right time on the part of policy making authorities in public sector banks to plan ways and means of how to attract customers not only in terms having mere accounts but make them frequent users of the product and services provided by the banks. Unless or otherwise some serious strategies are taken, there is every chance that the customers of public sector banks may close their accounts gradually and move forward to have accounts in private banks.

\subsection{Perception of Bank Customers on Automation}

The Categorical Principal Component analysis has been used for studying main items and its importance with respect to customers' view. The overall average scores for each main item has been computed based on the sub item scores and the findings are summarized. Based on the correlations of the original variables, the component loadings are computed and the same has been displayed with respect to two dimensions in Table 3.3.1. 
Table 3.3.1

Component Loadings

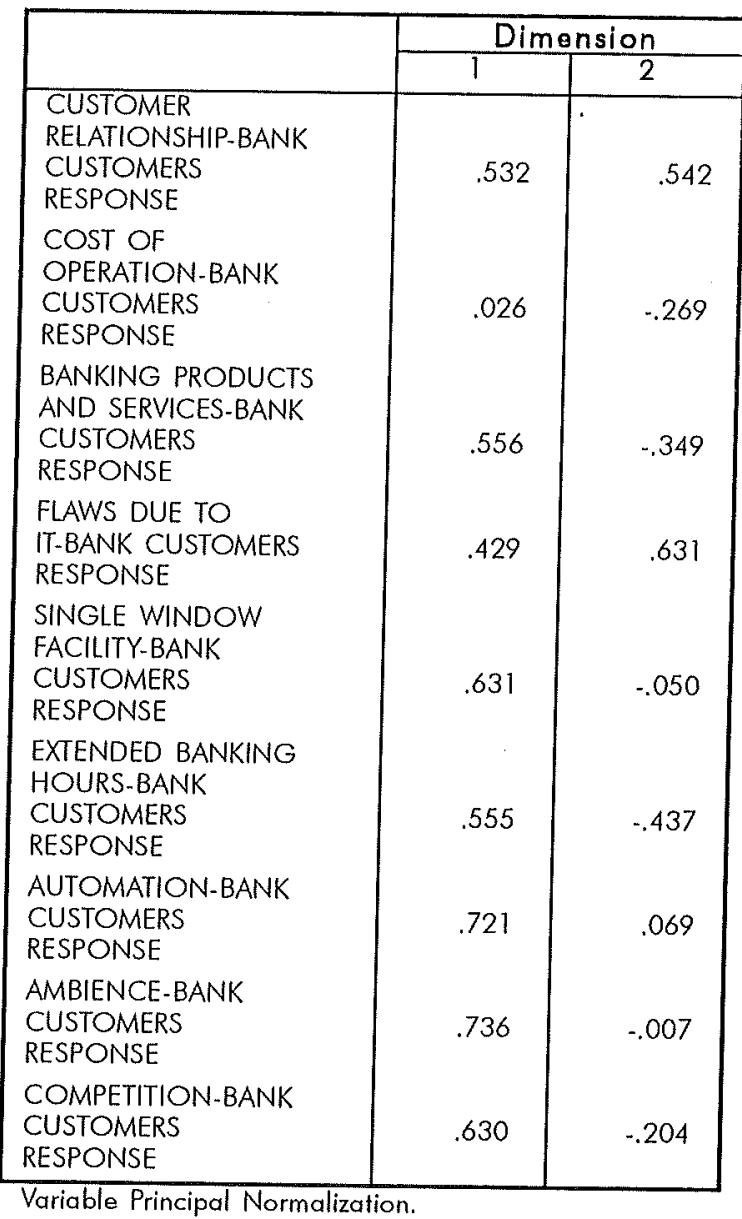

According to Bank customers' opinion on the nine major items, the following four sets have been formed using Table 3.3.1 and Fig. 3.3.1.

- Set 1 - Flaws due to IT have positive loadings in both the Dimensions and it is a crucial and significant factor according to the customers. Some customers commented that they were forced to do transactions on the next day and some others felt that bank officials are not quick enough to equip themselves in the newer technological development which leads to unwanted delay. Thus, customers find automation process has got some negative side as well, which is undeniable. 
$>$ Set 2 - Extended banking hours has positive loading in Dimension- 1 and negative loading in Dimension-2 and is found to be highly statistically significant. This option is a welcome move according to the customers and they found it very useful.

- Set 3 - Banking products/services and Customer relationship are to be given due importance. In order to emphasis special features in banking products/ services it is imperative to introduce IT. The real bonanza of implementation of IT enabling more banking products/services has got excellent support from the customers. However, the customer relationship has been reduced considerably after the introduction of IT as machine world dominates manpower to a large extent.

> Set 4-Ambience, Single window concept, Competition and Cost of operation explain less variation among the ratings given by the customers. Most of the customers use the bank for a routine and minimal bank operations and the time spent in the bank by them is meager. It is of the opinion by the customers that mere show in the banks will reflect in their service charges and hence they give less weightage to Ambience. Understandably, Competition is the botheration of Bank officials rather than customers.

Fig. 3.3.1

\section{Component Loadings}

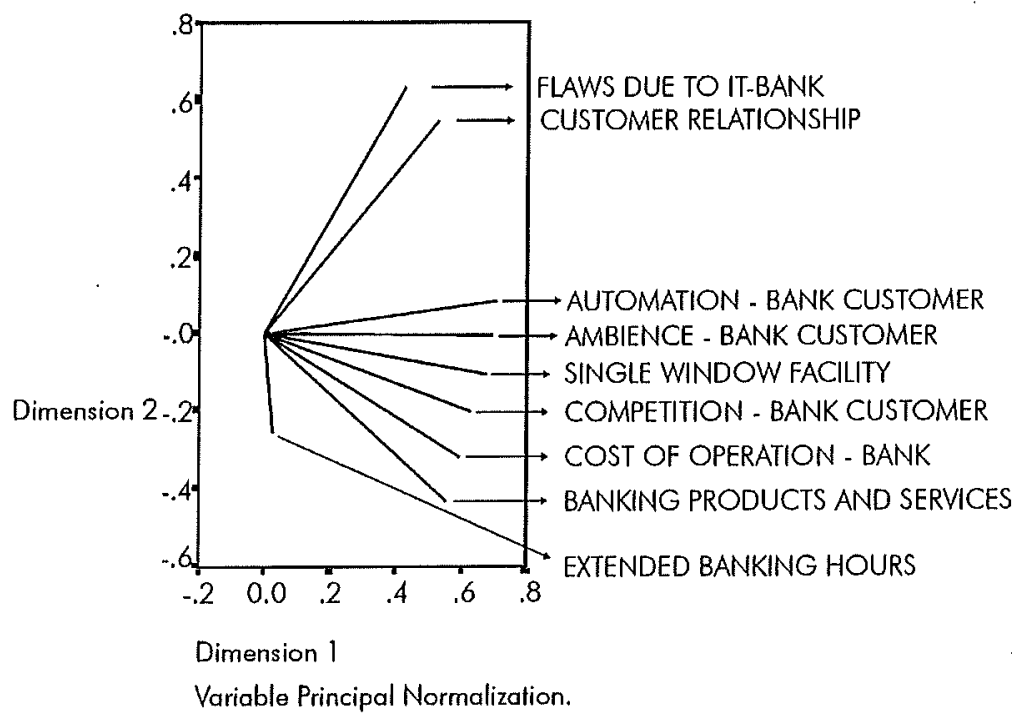




\subsection{Bank Customers - Overall Assessment - Before \& After Automation}

Non-Parametric paired test in the form of Wilcoxon signed Rank Test has been applied to study the situation in banks 'Before and After Automation' (Tables 3.4.1A-3.4.1C) with regard to customers' perception in various domains of Banking operations. On the whole, Bank customers are highly satisfied with automation utilities and services, which are presented in the hierarchical order based on the absolute calculated value of Standard normal variable $Z$ and its significance:

\section{Reduction in queue length}

Like the bank officials, customers also have the same opinion of advocating that the queue length has considerably reduced after automation $(Z=16.971, p=$ $0.000)$. IT inception has developed a better infrastructure in the banking industry which enables to process the routine transaction which has got an overwhelming support both from the bank customers and the officials of the public sector banks.

\section{Time taken to update the pass book}

Here again, both customers and the bank officials have the same opinion and the factor is highly statistically significant. Time factor has become crucial in the present days and the customers are made comfortable by speedy operation of the routine transaction, which is the outcome of automation $(Z=16.467$, $p=0.000)$.

\section{Banking hours}

The bank customers feel that the bank hours are enhanced (extended banking hours) and the customers staying time in the branch premise is also reduced after automation, giving a positive note to automation $(Z=15.737, p=0.000)$.

\section{Quality of the service offered}

The bank customers give due regard to the quality of the service offered by the banks after automation. It is statisfically significant for the fact that banks provide a better range of services after automation $(Z=15.214, p=0.000)$. 


\section{Pass book entry in the bank account}

The customers feel that the passbook entry has a better presentation with clarity, clear visual impact and up-to-date details is made possible only through automation. A new formatted pass book for easy print out provide a clear note of recorded transactions which in turn ease customers operation and avoid them to wait for clarification pertaining to the pass book $(Z=14.455$, $p=0.000)$.

\section{Range of services offered}

Of late, the public sector banks provide multifaceted services, which is made possible mainly due to automation, which is well supported by the bank customers by way of their responses and is statistically significant $Z=14.051$, $p=0.000)$.

\section{Loan disbursement}

Loan disbursement is made simpler in processing, attracting more customers to approach bank for getting the facility, leading to befter furnover and enhancing the goodwill of the banks. Follow up action is taken, debiting of interest charges, tracking the loan repayment are systematized only after automation $(Z=13.560$, $p=0.000)$.

\section{Ambience}

The customers of today are well informed and are in the position to compare the facilities and infrastructure of private banks where they have accounts with that in public sector banks. With the available infrastructure, it is possible now to make the banking operations more transparent. The public sector banks also face a mild threat of loosing customers if they don't wake up to the reality, which compels them for a better ambience $(Z=13.545, p=0.000)$.

\section{Settlement of deposit on maturity}

Automation facilitates intimation in advance regarding the date of settlement of deposits on maturity and it is well appreciated by the customers $(Z=13.342$, $p=0.000)$. 


\section{Overall services of the bank}

The customers have responded very positively on the overall services of the bank after automation $(Z=13.085, p=0.000)$.

\section{Closing the pre-matured deposit account}

As all banking operations are programmed in the system, anything and everything can be done and pre-closure involves lots of manual computation and is completely avoided through automation $(Z=12.195, p=0.000)$.

\section{Customer relation with bank staff}

Majority of the Customers have given the opinion that they are able to have rapport with bank officials as before and automation has no way distracted them $(Z=8.206, p=0.007)$.

\section{Wilcoxon Signed Ranks Test}

Table 3.4.1 A

Ranks

\begin{tabular}{|c|c|c|c|c|}
\hline & & $\mathrm{N}$ & Mean Rank & Sum of Ranks \\
\hline $\begin{array}{l}\text { PASS BOOK ENTRY - } \\
\text { PASS BOOK ENTRY }\end{array}$ & $\begin{array}{l}\text { Negative Ranks } \\
\text { Positive Ranks } \\
\text { Ties } \\
\text { Total }\end{array}$ & $\begin{array}{r}55 \\
355 \\
262 \\
672\end{array}$ & $\begin{array}{l}182.71 \\
209.03\end{array}$ & $\begin{array}{l}10049.00 \\
74206.00\end{array}$ \\
\hline $\begin{array}{l}\text { TIME TAKEN TO UPDATE } \\
\text { THE PASS BOOK - } \\
\text { TIME TAKEN TO UPDATE } \\
\text { THE PASS BOOK }\end{array}$ & $\begin{array}{l}\text { Negative Ranks } \\
\text { Positive Ranks } \\
\text { Ties } \\
\text { Total }\end{array}$ & $\begin{array}{r}47 \\
419 \\
\\
206 \\
672 \\
\end{array}$ & $\begin{array}{l}203.33 \\
236.88\end{array}$ & $\begin{array}{r}9556.50 \\
99254.50\end{array}$ \\
\hline $\begin{array}{l}\text { REDUCTION IN QUEUE } \\
\text { LENGTH - REDUCTION } \\
\text { IN QUEUE LENGTH }\end{array}$ & $\begin{array}{l}\text { Negative Ranks } \\
\text { Positive Ranks } \\
\text { Ties } \\
\text { Total }\end{array}$ & $\begin{array}{r}36 \\
418 \\
216 \\
670 \\
\end{array}$ & $\begin{array}{l}176.92 \\
231.86\end{array}$ & $\begin{array}{r}6369.00 \\
96916.00\end{array}$ \\
\hline $\begin{array}{l}\text { LOAN DISBURSEMENT - } \\
\text { LOAN DISBURSEMENT }\end{array}$ & $\begin{array}{l}\text { Negative Ranks } \\
\text { Positive Ranks } \\
\text { Ties } \\
\text { Total }\end{array}$ & $\begin{array}{r}34 \\
292 \\
341 \\
667\end{array}$ & $\begin{array}{l}151.18 \\
164.93\end{array}$ & $\begin{array}{r}5140.00 \\
48161.00\end{array}$ \\
\hline
\end{tabular}


Test Statistics

\begin{tabular}{|c|c|c|c|c|}
\hline & $\begin{array}{l}\text { PASS BOOK } \\
\text { ENTRY - } \\
\text { PASS BOOK } \\
\text { ENTRY } \\
\end{array}$ & $\begin{array}{l}\text { TIME TAKEN } \\
\text { TO UP DATE } \\
\text { THE PASS } \\
\text { BOOK - TIME } \\
\text { TAKEN TO } \\
\text { UPDATE THE } \\
\text { PASS BOOK } \\
\end{array}$ & $\begin{array}{l}\text { REDUCTION } \\
\text { IN QUEUE } \\
\text { LENGTH - } \\
\text { REDUCTION } \\
\text { IN QUEUE } \\
\text { LENGTH } \\
\end{array}$ & $\begin{array}{c}\text { LOAN } \\
\text { DISBURSEMENT } \\
\text { - LOAN } \\
\text { DISBURSEMENT }\end{array}$ \\
\hline $\begin{array}{l}\text { Z } \\
\text { Asymp. Sig. (2-tailed) }\end{array}$ & $\begin{array}{r}-14.455^{\circ} \\
.000\end{array}$ & $\begin{array}{r}-16.467^{\circ} \\
.000\end{array}$ & $\begin{array}{r}-16.971^{\circ} \\
.000\end{array}$ & $\begin{array}{r}-13.560^{\circ} \\
.000\end{array}$ \\
\hline
\end{tabular}

a. Based on negative ranks.

b. Wilcoxon Signed Ranks Test

Table 3.4.1 B

Ranks

\begin{tabular}{|c|c|c|c|c|}
\hline & & $N$ & Mean Rank & Sum of Ranks \\
\hline $\begin{array}{l}\text { SETTLEMENT OF } \\
\text { DEPOSIT ON MATURITY } \\
\text { - SETTLEMENT OF } \\
\text { DEPOSIT ON MATURITY }\end{array}$ & $\begin{array}{l}\text { Negative Ranks } \\
\text { Positive Ranks } \\
\text { Ties } \\
\text { Total }\end{array}$ & $\begin{array}{r}30 \\
281 \\
356 \\
667\end{array}$ & $\begin{array}{l}155.02 \\
156.01\end{array}$ & $\begin{array}{r}4677.50 \\
43838.50\end{array}$ \\
\hline $\begin{array}{l}\text { CLOSING THE PRE } \\
\text { MATURED DEPOSIT AVC } \\
\text { - CLOSING THE PRE } \\
\text { MATURED DEPOSIT AVC }\end{array}$ & $\begin{array}{l}\text { Negative Ranks } \\
\text { Positive Ranks } \\
\text { Ties } \\
\text { Total }\end{array}$ & $\begin{array}{r}45 \\
278 \\
\\
343 \\
666\end{array}$ & $\begin{array}{l}161.62 \\
162.06\end{array}$ & $\begin{array}{r}7273.00 \\
45053.00\end{array}$ \\
\hline $\begin{array}{l}\text { CUSTOMER RELATION } \\
\text { WITH BANK STAFF - } \\
\text { CUSTOMER RELATION } \\
\text { WITH BANK STAFF }\end{array}$ & $\begin{array}{l}\text { Negative Ranks } \\
\text { Positive Ranks } \\
\text { Ties } \\
\text { Total }\end{array}$ & $\begin{array}{r}80 \\
233 \\
\\
358 \\
671\end{array}$ & $\begin{array}{l}155.48 \\
157.52\end{array}$ & $\begin{array}{l}12438.00 \\
36703.00\end{array}$ \\
\hline $\begin{array}{l}\text { BANKING HOURS - } \\
\text { BANKING HOURS }\end{array}$ & $\begin{array}{l}\text { Negative Ranks } \\
\text { Positive Ranks } \\
\text { Ties } \\
\text { Total }\end{array}$ & $\begin{array}{r}31 \\
354 \\
286 \\
671\end{array}$ & $\begin{array}{l}147.71 \\
196.97\end{array}$ & $\begin{array}{r}4579.00 \\
69726.00\end{array}$ \\
\hline
\end{tabular}


Test Statistics ${ }^{b}$

\begin{tabular}{|c|c|c|c|c|}
\hline . & $\begin{array}{c}\text { SETTLEMENT } \\
\text { OF DEPOSIT } \\
\text { ON MATURITY } \\
\text { - } \\
\text { SETTLEMENT } \\
\text { OF DEPOSIT } \\
\text { ON MATURITY }\end{array}$ & $\begin{array}{c}\text { CLOSING } \\
\text { THE PRE } \\
\text { MATURED } \\
\text { DEPOSIT AVC-- } \\
\text { CLOSING } \\
\text { THE PRE } \\
\text { MATURED } \\
\text { DEPOSIT A/C } \\
\end{array}$ & $\begin{array}{c}\text { CUSTOMER } \\
\text { RELATION } \\
\text { WITHBANK } \\
\text { STAFF - } \\
\text { CUSTOMER } \\
\text { RELATION } \\
\text { WITH BANK } \\
\text { STAFF } \\
\end{array}$ & $\begin{array}{l}\text { BANKING } \\
\text { HOURS - } \\
\text { BANKING } \\
\text { HOURS }\end{array}$ \\
\hline $\begin{array}{l}\text { Z } \\
\text { Asymp. Sig. (2-tailed) }\end{array}$ & $\begin{array}{r}-13.342^{a} \\
.000\end{array}$ & $\begin{array}{r}-12.195^{\circ} \\
.000\end{array}$ & $\begin{array}{r}-8.206^{\circ} \\
.000\end{array}$ & $\begin{array}{r}-15.737^{\circ} \\
.000\end{array}$ \\
\hline
\end{tabular}

a. Based on negative ranks.

b. Wilcoxon Signed Ranks Test

Table 3.4.1 C

Ranks

\begin{tabular}{|ll|r|c|c|}
\hline & & N & Mean Rank & Sum of Ranks \\
\hline AMBIENCE - AMBIENCE & Negative Ranks & 34 & 125.00 & 4250.00 \\
& Positive Ranks & 278 & 160.35 & 44578.00 \\
& Ties & 356 & & \\
& Total & 668 & & \\
\hline RANGE OF SERVICES & Negative Ranks & 42 & 169.83 & 7133.00 \\
OFFERED - RANGE OF & Positive Ranks & 322 & 184.15 & 59297.00 \\
SERVICES OFFERED & Ties & 307 & & \\
& Total & 671 & & 4161.00 \\
\hline QUALITY OF THE & Negative Ranks & 26 & 160.04 & 57967.00 \\
SERVICES OFFERED - & Positive Ranks & 326 & 177.81 & \\
QUALITY OF THE & Ties & 319 & & 6018.50 \\
SERVICES OFFERED & & & & 46956.50 \\
& Total & 671 & & \\
\hline OVERALL SERVICES OF & Negative Ranks & 38 & 158.38 & \\
THE BANK - OVERALL & Positive Ranks & 287 & 163.61 & \\
SERVICES OF THE BANK & Ties & 347 & & \\
& Total & 672 & & \\
\hline
\end{tabular}


Test Statistics

\begin{tabular}{|c|c|c|c|c|}
\hline & 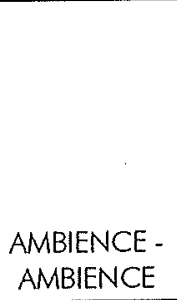 & $\begin{array}{l}\text { RANGE OF } \\
\text { SERVICES } \\
\text { OFFERED - } \\
\text { RANGE OF } \\
\text { SERVICES } \\
\text { OFFERED }\end{array}$ & $\begin{array}{c}\text { QUALITY OF } \\
\text { THE } \\
\text { SERVICES } \\
\text { OFFERED - } \\
\text { QUALITY OF } \\
\text { THE } \\
\text { SERVICES } \\
\text { OFFERED }\end{array}$ & $\begin{array}{l}\text { OVERALL } \\
\text { SERVICES OF } \\
\text { THE BANK- } \\
\text { OVERALL } \\
\text { SERVICES OF } \\
\text { THE BANK }\end{array}$ \\
\hline $\begin{array}{l}\text { Z Asymp. Sig. (2-tailed) } \\
\text { As. }\end{array}$ & $\begin{array}{r}-13.545^{\circ} \\
.000\end{array}$ & $\begin{array}{r}-14.051^{\circ} \\
.000\end{array}$ & $\begin{array}{r}-15.214^{a} \\
.000\end{array}$ & $\begin{array}{r}-13.085^{\circ} \\
.000\end{array}$ \\
\hline
\end{tabular}

a. Based on negative ranks.

b. Wilcoxon Signed Ranks Test

\subsection{Significant Domains of Banking Operations}

In section 3.4, Wilcoxon Signed Rank test has been applied to study each of the 11 domains individually for its statistical significance towards before and after automation. In this section, two-group discriminant and classification analysis has been carried out to identify the significant domains that discriminate between before and after automation. Table 3.5.1 reveals that there are only 7 domains out of 11 discriminate the above two situations and are found to be highly statistically. significant. Based on the classification function coefficients given in Table 3.5.2, we infer that when comparison was made between before and after automation, the domains reduction in queve length, Banking hours, time taken to update the pass book and loan disbursement were highly commended from the perception of bank customers and they are fully benefited through automation. However, the customer relationship with the bank officials has been reduced considerably as per the reflections of the customers. Automation has also positively commented with the crucial and important features like 'Quality of service offered by the banks and neat presentation in Pass book entry'. The classification results provided in Table 3.5.3 reveals that the responses expressed by the bank customers were correctly classified to the extent of $78.8 \%$ with respect to before and after qutomation groups. 
Table 3.5.1

Variables Entered/Removed $a, b, c, d$

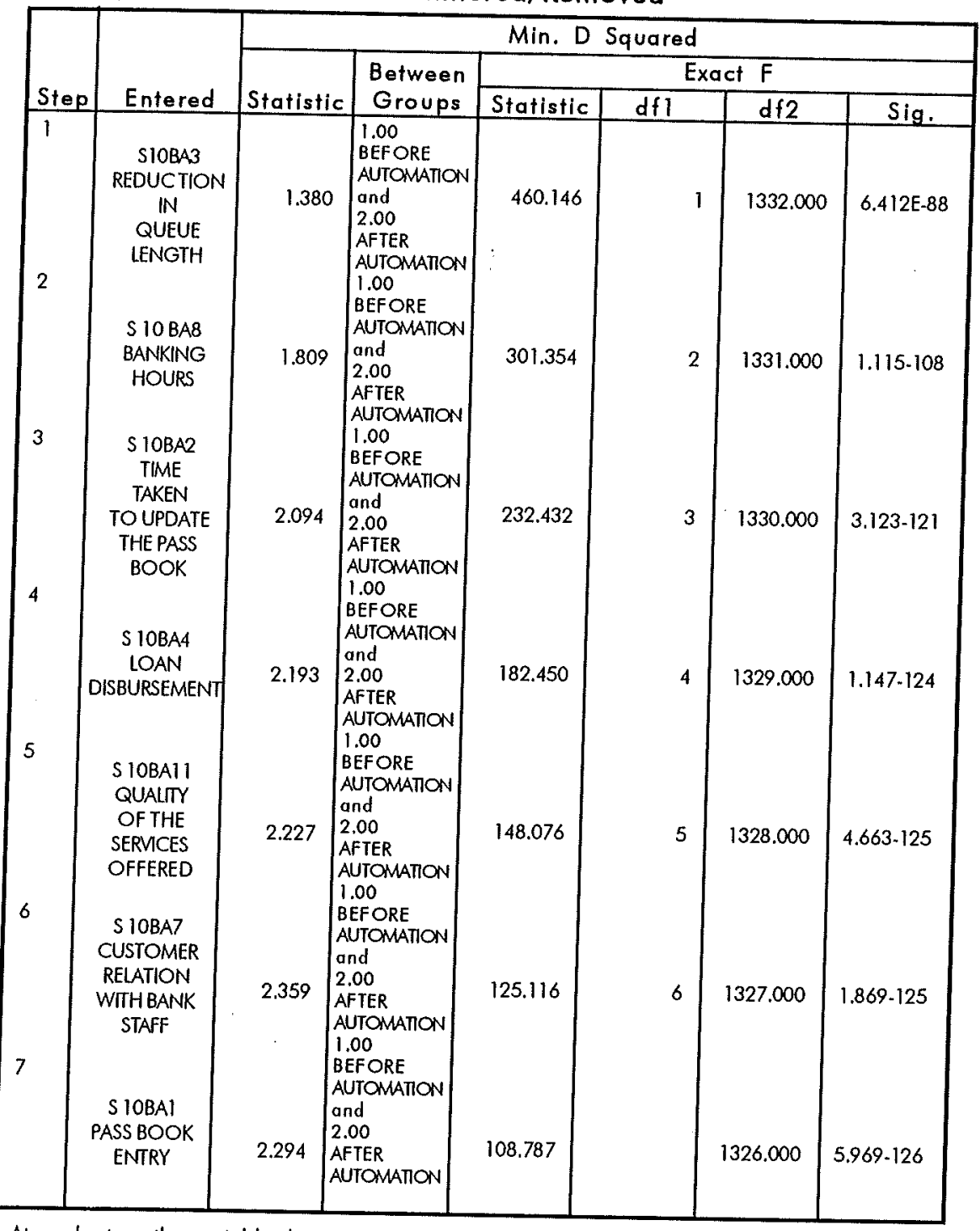

At each step, the variable that maximizes the Mahalanobis distance between the two closets groups is entered

a. Maximum number of steps is 24 .

b. Minimum partial $F$ to enter is 3,84 .

c. Maximum partial $F$ to remove is 2.71 .

d. F level, tolerance, or VIN in sufficient for further computation. 
Table 3.5.2

Classification Statistics

Classification Function Coefficients

\begin{tabular}{|c|c|c|}
\hline & \multicolumn{2}{|c|}{ GROUP GROUP } \\
\hline & $\begin{array}{l}1.00 \text { BEFORE } \\
\text { AUTOMATION }\end{array}$ & $\begin{array}{c}2.00 \text { AFTER } \\
\text { AUTOMATION }\end{array}$ \\
\hline $\begin{array}{l}\text { SIOBAI PASS BOOK } \\
\text { ENTRY }\end{array}$ & .250 & .322 \\
\hline $\begin{array}{l}\text { SIOBA2 TIME TAKEN } \\
\text { TO UPDATE THE } \\
\text { PASS BOOK }\end{array}$ & .082 & .235 \\
\hline $\begin{array}{l}\text { SIOBA3 REDUCTION } \\
\text { IN QUEUE LENGTH }\end{array}$ & -102 & .069 \\
\hline $\begin{array}{l}\text { SIOBA4 LOAN } \\
\text { DISBURSEMENT }\end{array}$ & .194 & .296 \\
\hline $\begin{array}{l}\text { S1OBA7 CUSTOMER } \\
\text { RELATION WITH } \\
\text { BANK STAFF } \\
\text { S1OBA8 BANKING }\end{array}$ & .210 & .137 \\
\hline $\begin{array}{l}\text { HOURS } \\
\text { SIOBAII QUALITY OF }\end{array}$ & .128 & .298 \\
\hline THE SERVICES & .183 & .274 \\
\hline OFFERED (Constant) & -2.641 & -5.976 \\
\hline
\end{tabular}

Fisher's linear discriminant functions

Table 3.5.3

Classification Results

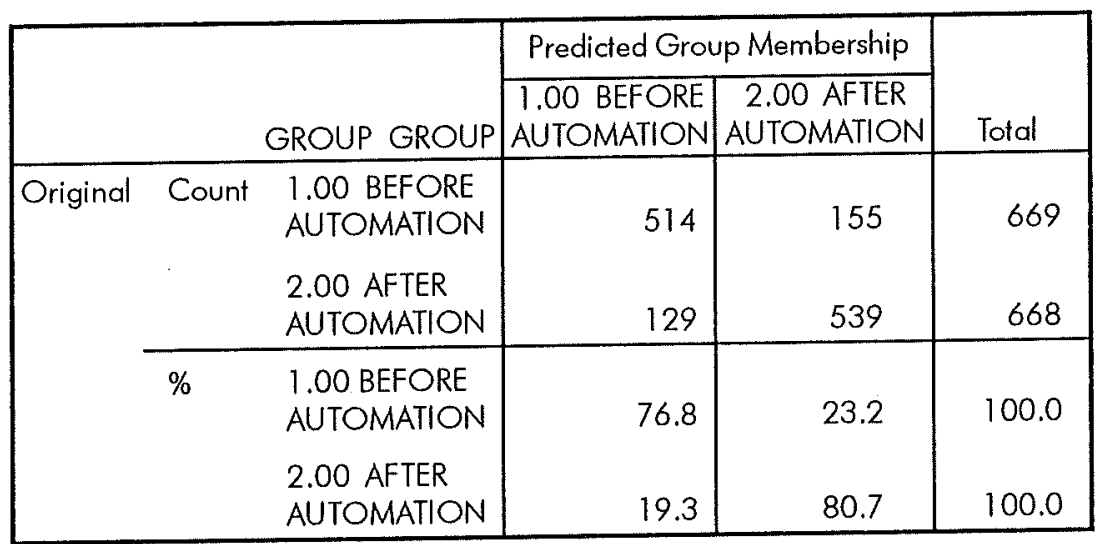

a. $78.8 \%$ of original grouped cases correctly classified. 


\subsection{Suggestions to the Policy makers of the Public Sector Banks}

The present study is the outcome of a survey which includes 674 bank customers of the public sector banks who have various types of bank accounts in the branches of Chennai city. Branches of public sector banks in Chennai city, consisting of 19 nationalized banks and State Bank of India with its 7 Associates were covered in the survey. The opinion expressed by the bank customers on Automation has been thoroughly investigated and the following suggestions are recommended:

$\checkmark$ System failure in the peak hour disrupts the work in the public sector banks. This makes the customers to switch over to other banks where the facility of alternative arrangement is better. To avoid this, the public sector banks should think in terms of a better technical support.

$\checkmark$ Most of the customers do not know the ranges of products and services offered by the banks and they do not benefit out of it. Instead of merely displaying the information in the branches through posters and banners, media could be used intensively for this purpose.

$\checkmark$ Single Window Facility needs to be focused towards optimizing the time as most of the banks have this provision, but takes the same time as that of normal counter.

$\checkmark$ To compete with private sector banks, the possibilities of offering Any Time Any Where Banking concept and taking 'Bank to Customer concept' can be explored.

$\checkmark$ To reach out customers effectively, new avenues of banking could be tried like creating customer database to transmit information about new products/services, changes in interest rates, instant banks balance etc.

\subsection{Concluding Remarks}

The public sector banks are unique in various aspects and they cannot function like private sector banks by keeping only profit as the prime motive. They have to compromise between various issues like satisfying the new generation customers, retaining the existing customer base, adhering to the policies and directives of Reserve Bank and the Government and above all keeping the bank staff with all comforts. The study came out with remarkable findings on the basis of selected perceptions of the bank customers of the public sector banks. It is interesting to observe that the bank customers are positive towards technological upgradation. 


\section{References}

- Doreswamy S. (1997): 'Perspectives in Indian Banker's Association', Special Issue, March 1997, P.63.

- Kaujalgi V.B (1999): 'Bank Automation in India - Transition to next millennium', Management Review, Vol. 11, No.2, Pp.75-80.

- Madan Goyal (1994):' Automation in Banks', The Banker, Dec. 1994, P.73.

- Marcus A. (2006): 'A Study on Information Technology Perspective in the Indian Banking Industry with reference to Public Sector Banks in Chennai City', Unpublished Ph.D. thesis submitted to University of Madras.

- Raman K.J. and Marcus A. (2007): 'Impact of Automation in Public Sector Banks as per the reflections of Customers and bank officials', Accepted for publication in "The SPSS Analyst", South Asia.

- Rao (2002): 'Changing Indian Banking Scenario: A Paradigm Shiff', IBA Bulletin, Vol. XXIV, No.1, Pp.12-20. 